\title{
Educational Rights of the Children in Conflict Zones
}

\author{
Shaikh Shamshul Aarfin \\ Ph. D Scholar \\ Dr. K. R. Narayanan Centre for Dalit and Minorities Studies, Jamia Millia Islamia, New Delhi, India
}

\begin{abstract}
The educational rights of the children is quite often violated in the conflict affected areas. They are deprived from the basic fundamental right that is guaranteed by the constitution, and an important covenant of the United Nations CRC article. Children living in these areas are at risk they often forced to drop their education and engaged in the economic activities. Quite often they also become a part of child soldier and work as a helper which creates wastage in terms of educational year. UNESCO (1990) declared that "No country can use the benefits of science and technology on the scale necessary for is development if population includes a high percentage of illiterates".
\end{abstract}

Keywords - Conflict, Children, Education, Rights, Society

\section{INTRODUCTION}

After independence we adopted one of the finest constitutions of the world; guarantees many rights to its citizens and promotes for a healthy and fruitful environment, education is one of them. In 2002, Govt. of India amended the constitution for $86^{\text {th }}$ time and incarnated article $21 \mathrm{~A}$ as fundamental rights, aiming to provide education to all the children between the age group of 6-14 years with a constitutional guarantee. In 2009, Right to Education act came into existence which describes the modalities of the importance of free and compulsory education for above mentioned age group children in India under Article 21a of the Indian Constitution. Prior to this amendment, though many articles in the constitution which had talked about education but none of them guaranteed the free education. In India, around 23\% children are between 6-14 years and out of them 40\% are living in conflict prone areas. Data shows that there has been a marginal improvement in the percentage of students who stay in school until Class 5 -- from $61.2 \%$ to $62 \%$-- but this is way below the global average of $83.3 \%$.Though the constitution says that education is a 'Fundamental Right' but it seems that the system is designed to push children out of education -- there is a lack of adequate school infrastructure, mostly in suburban areas, the quality of education is also debatable, in some sense, the educational system is genderunfriendly, disabled-unfriendly, caste-discriminatory and violent because of a high degree of corporal punishment.

However, the purpose of writing this piece is to show the child education in conflict which is locally (especially in Indian context) treated as charity rather than right. My intention regarding education is specific with emergency situation; refers to the provision of formal and non-formal education in situations where children lack access to the government or community education systems. It is often identified as because of armed-conflicts or natural disasters. It encompasses non-formal education programmes. These are often set up in the immediate wake of an emergency and the establishment or reintroduction of formal government, community or other sustainable education systems during the transition and post-conflict or -crisis periods. Contextualising this, Conflict is actual or perceived opposition of needs, values and interests. A conflict can be internal (within oneself) to individuals. Conflict as a concept can help explain many aspects of social life such as social disagreement, conflicts of interests, and fights between individuals, groups, or organizations. In political terms, 'conflict' can refer to wars, revolutions or other struggles, which may involve the use of force as in the case of armed conflict. Without proper social arrangement or resolution, conflicts in social settings can result in stress or tensions among stakeholders. When an interpersonal conflict occurs, its effect is often reaches to the place unknown and sometime results into worst form. It is also observed that because of inequalities in the political, cultural and socioeconomic spheres are fundamental risks which make government or state to treat inequitably.

\section{CHILD EDUCATION AND CONFLICT: A PERSPECTIVE}

Children's education is often disrupted during emergencies whether they are caused by armed conflict or natural disaster or mass agitation. Sometime children never return to school when the emergency is over, significantly diminishing their own opportunities and their country's ability to break the cycle of poverty and underdevelopment. In the context of India, most analyses of armed conflict willy-nilly overlook the issue of children as well. UNESCO (1990) declared that "No country can use the benefits of science and technology on the scale necessary for is development if population includes a high percentage of illiterates". 
In current intra-state, ethno-political conflicts, children lay an increasing role both as soldiers and, along with other non-combatants, as targets and victims in fighting at the community level in general. This leads for an increasing participation in political violence of children at local and regional level. Apart from this, many children have little schooling, job training, or other means of meeting their basic needs, presents profound obstacles to the construction of peace. Furthermore, current patterns of community-level fighting victimize children, enabling soldiering and the continuation of cycles of armed conflict. Of the estimated 72 million primary school-age children out of school worldwide, as many as 25 million live in countries affected by conflict.

In terms of providing rights to the children, all children have a right to equal and quality education in all situations and at all times, including in emergencies. Education has been formally recognized as a human right since the adoption of the Universal Declaration of Human Rights in 1948. Since then, the right to education has been affirmed in numerous global treaties, including the Convention on the Rights of the Child (CRC). Article 28 encourages the development of general and vocational education, as well as educational guidance that is available and accessible to every child. It also states that measures should be taken to encourage regular attendance at schools and that discipline should be administered in a manner consistent with the child's human dignity. Article 29 of the CRC states "that education of the child shall be directed to the development of a child's personality, talents, and mental and physical abilities to their fullest potential". These treaties establish an entitlement to free, compulsory primary education for all children and an obligation by duty-bearers to develop equitable quality secondary and higher education. They further establish the multiple aims of education: to promote personal development; to strengthen respect for human rights and freedoms; to enable individuals to participate effectively in society; and to promote understanding, friendship and tolerance. Indeed, education is an indispensable foundation for the fulfillment of any civil, political, economic and social rights.

Although the right to education is deeply rooted in Indian law, the practice often lags far behind. India's Constitution guarantees that "The State shall provide free and compulsory education to all children of the age of six to fourteen years." The Constitution further states that "The State shall, within the limits of its economic capacity and development, make effective provision for securing the right to education and places a duty upon the state to promote with special care the educational interests of the weaker sections of the people.

Today countries from Middle East, South Asia, South-East Asia and Africa have some sort of conflicts which lead them to a depriving situation. The nature of conflicts in these regions is experiencing almost with unanimous issues namely; civil war, ethnic riots, poverty etc. It is analysed that major factor behind it; is because of various forms of capitalist plans which always advocate certain power-centric narrative, with slight expansionist ideas on the cost of human's life. In this regard, children are most vulnerable not only in terms of facing atrocities from but also receiving right-based facilities in general. For example, almost 25 million children of total world population are out-of-school just mainly because of armed conflict. Conflict prone areas also play a vital role which often causes to a large scale migration. In this situations, people do not find themselves enough motivated to think their children's education. If some of them are cared and provided education even through the conflict zone experiences, their time is wasted in formalities which create barriers in the path of accessing their education. However, the importance of providing education affected by conflict has a long history. In this context, experiences of WWII brought developments like International Convention on the Right of the Child (focusing on education), international educations for all agenda and Millennium Development Goals each of them set time bound targets to achieve universal right to education. Even governmental and nongovernmental network for this purpose is also functioning.

\section{SITUATION IN INDIA}

India is one of those countries whose policies on child education produces or come up with many paradoxes in which child labor is at the top. There are many complicated explanations for this. Apart from this, education in India has been always a matter of concern, specially, in areas like Bihar, Jharkhand, Manipur, Odisha or Kashmir. These areas were always in conflict with state and made an unavoidable situation of war and violence, for instance, Naxalites and Militants. Conflicts in these areas made children more vulnerable as possibilities for receiving education collapse. On the other hand, strategic confrontation between state and partyin-conflict requires recruitment which is done by picking minor school-going students in order to organize their own anti-state wing. Further, security issue for school's staff, mostly in conflict zones also leads an unaccountable behavior. In case of internal conflicts, brutal political strategies like Gujarat riots leave schools unable to function. Sometime natural disaster brings unimaginable grievances to the educational infrastructures of a country as in the case of Tsunami in Tamil Nadu which caused heavy dropouts of students. Therefore, the 
lack of a safe and protective environment for education, children are faced with various other risks like trafficking to cities to work as child labourers.

According to Yamina de Laet of the International Chemical, Energy and Mine Workers' federation (ICEM), children aged 6-14 years represent $40 \%$ of the labour force in the precious-stone-cutting sector. Many children are working as labourer which is considered as 'non-hazardous' such as agricultural sector, domestic work, roadside restaurants, sweetmeat shops, automobile mechanic units, rice mills, Indian Made Foreign Liquor (IMFL) outlets where they have been exploited by their employer. Rescue operations in Mumbai and Delhi in 2005-2006 highlight the employment of children in zari and embroidery units. India has the highest number of child labourers in the world. Census reports clearly point to an increase in the number of child labourers in the country, from 11.28 million in 1991 to 12.59 million in 2001 . One of the organization in India reveals that nearly 400,000 children, mostly girls between 7 and 14 years of age, strive and struggle for 14-16 hours a day in cotton seed production across the country.

However, in terms of educational infrastructure, mostly in urban areas, India has developed an appreciative character. But in terms of providing education to all on egalitarian basis the case seems disappointing. Though the visible growth in education sector such as instruments of Special Education Zones, Rural Education, World Bank’s initiatives played an important role.

In Odisha, during the protest of POSCO mega power plant, many children were out of school because their classrooms were occupied by the security forces. In an environment of disturbance and protest students cannot able to concentrate on their studies. "In school, they teach us the story of Baji Rout." (A 13-year-old boatman and legendary Oriya hero shot dead by the British when he refused to ferry them across a river in pursuit of freedom fighters) "They tell us, "you should emulate Baji Rout and the way he stood up for his homeland. But when we stand up for ours, they react badly." Their parents are the part of the protest, how the children will be in the school when they know that their parents are fighting for their home and livelihood. Some of the students have seen the police using rubber bullet on their parents, therefore, they were not able to come to school where the security forces are deployed. Similarly, children in other parts of the state such as Koraput, Malkangiri etc. which are considered as 'Red Zones' are also facing the same situation, the only difference is actors changed. In POSCO nearby area police rather state and in Red Zones Maoist are responsible for the obliteration of children's education and their future.

Similarly, in Assam, during the Kokrajhar riot, lakhs of people were displaced. Thousands of children have to live in relief shelters for months. They were forced to drop the schools as it was also destroyed in the riot. Children have to spend many days without textbooks and forced to enjoy the unwanted holidays. Some of the schools were converted into relief centers for the many displaced people during the massacre. It was also reported that many young children dropped their schooling as they was no one to take care of their education and livelihood.

After the bifurcation of Chattisgarh it was considered that the problem of naxalites will be effectively addressed and development in all field will be easily be done, but situation is still not changed. As we have seen in the previous case studies, here many schools were shutdown due to conflict between the state and the Naxalites. Many schools were destroyed and people were threatened that if they send their child to school it will not be good for them. In many cases children were getting victimized by the police in wrong cases. Many students were picked by security forces for interrogation and put them behind the bar on the basis of doubt. In these entire environment Children's childhood has badly affected and many children became labourer. Those children who lost their parents due to the ongoing conflict are more vulnerable because they become the soft target of the naxalites and in many cases become child soldier.

\section{EDUCATION FOR PEACE}

Education is an important intervention in emergencies, as it can provide physical, psychosocial and cognitive protection to children, and often remains a high priority for children and parents even amidst emergencies. Re-establishing education in communities and system-wide following a crisis can have an important stabilizing effect, serve as a peace dividend in countries emerging from conflict and help reduce disaster risk. Education also provides an essential foundation for the realization of many other development goals.

Case studies from different parts of the conflict prone areas proved that these areas do have schools; not as equipped as it should be. In spite of this, community's aspirations to seek education for their generation are quite stronger. Though, being in a Naxal influenced areas they had to send their children for the training against the state. This attitude of the community and parents encourages a ray of hope for peace in the region. 


\section{CONCLUSION}

Therefore the government should not make policies that seem very good on paper but when it comes to implementation, it seems that they are doing charity and mercy on the children who are the actual beneficiaries of the various schemes run by the govt. such as Sarva Shiksha Abhiyaan. In reality govt., completely failed to address the problem of these children, who desperately need proper attention, if we leave their problem unattended then we are throwing them into a plethora of disaster. They may become a part of the labour (child) force or may be the part of anti social element which we already discussed above or they become anti-social elements. Their attitude and aspirations for education brings a ray of hope for peace in the region.

\section{REFERENCES}

[1]. Census 2001, India.

[2]. Education For All Global Monitoring Report, 2005, (UNESCO's Education For All Development Index (EDI) for 2004)

[3]. http://infochangeindia.org/agenda/child-rights-in-india/status-of-children-in-india.html accessed on 15 th March 2014.

[4]. Education in Conflict and Transition Context: Case studies from Democratic republic of Congo, Nepal, and Southern Sudan. P5.

[5]. Education Children in Conflict Zones, p. 6

[6]. United Nations Educational, Scientific and Cultural Organization, EFA Global Monitoring Report: Reaching the Marginalized, UNESCO Publishing, Paris, 2010

[7]. The right to education is also articulated in the Geneva Convention (IV) Relative to the Protection of Civilian Persons in Time of War (1949), the Convention against Discrimination in Education (1962), the Covenant on Economic, Social and Cultural Rights (1966), the Convention on the Elimination of Discrimination against Women (1979); and the Convention on Elimination of all Forms of Racial Discrimination (1965). The right to education was reaffirmed in the Dakar World Education Forum Framework for Action (2000), which promoted Education for All, and the Millennium Development Goals (2000).

[8]. The United Nations Convention on the Rights of the Child, UNICEF UK.

[9]. United Nations Children's Fund and United Nations Educational, Scientific and Cultural Organization, A Human Rights-Based Approach to Education for All, UNICEF and UNESCO, New York, 2008, p. 7.

[10]. UNICEF, New York 2010.

[11]. Educating Children in Conflict Zones ......pp. 8-9

[12]. Caught in Crossfire, Save the Children, India 2013.

[13]. 'Status of Children in India Inc', HAQ: Centre for Child Rights, 2005, page 176

[14]. Census of India 1991 and Census of India 2001

[15]. HAQ: Centre for Child Rights, 'Status of Children in India Inc', 2005, page 169

[16]. http://www.thehindu.com/opinion/op-ed/never-let-school-interfere-with-your-education/article2248021.ece accessed on 10th March 2014.

[17]. Red Zone refers to the Maoist or Naxal affected areas.

[18]. Caught in cross fire, save the children India, 2013.

[19]. Caught in cross fire, save the children India, 2013. 